\title{
Management of sellar and parasellar tumors becoming symptomatic during pregnancy: a practical algorithm based on multi-center experience and systematic literature review
}

\author{
Matteo Zoli ${ }^{1,2}$ D Federica Guaraldi ${ }^{1,2} \cdot{\text { Cesare } \text { Zoia }^{3} \cdot \text { Emanuele La Corte }^{1} \cdot \text { Sofia Asioli }}^{2,4} \cdot$ Daniele Bongetta $^{5}$. \\ Arianna Rustici ${ }^{6}$. Diego Mazzatenta ${ }^{1,2}$
}

Accepted: 3 November 2020 / Published online: 17 November 2020

(c) The Author(s) 2020

\begin{abstract}
Introduction Sellar/parasellar tumors (SPTs) very rarely become symptomatic during pregnancy. No specific guidelines exist for their management, that is extremely challenging as mother and fetus health can be jeopardized.

Materials and methods Data of patients with SPTs becoming symptomatic during pregnancy treated at two Italian referral Centers were retrospectively collected. Systematic literature review was also performed.

Results Our series consisted of 6 cases, 3 meningiomas, 1 ACTH-secreting adenoma, 1 pituicytoma and 1 craniopharyngioma. Mean age at presentation was $33.6 \pm 6.0$ years. Five patients complained of visual disturbances, associated with headache in one case, that occurred between gestation week (GW) 22 and 34. In 5 cases, pregnancy was uneventful with the delivery of a healthy baby between GW 33 and 35, followed by endoscopic surgical tumor exeresis $(n=4)$ or proton bean therapy $(n=1)$. Another patient presented with stigmata typical of Cushing's syndrome and rapidly worsening pre-eclampsia, that required pregnancy interruption and adenomectomy. Based on personal and literature cases, a practical algorithm was proposed to help clinicians dealing with these patients.

Conclusions SPTs becoming symptomatic in pregnancy deserve careful monitoring and multidisciplinary management. Overall, wait-and-see approach is suggested, reserving surgery to patients with rapidly progressive/life-threatening situations, significant risk of permanent neurological impairment or malignant lesions.
\end{abstract}

Keywords Pituitary tumors $\cdot$ Pituitary adenoma $\cdot$ Meningioma $\cdot$ Pregnancy $\cdot$ Management $\cdot$ Outcome

Matteo Zoli and Federica Guaraldi have equally contributed to the manuscript.

Matteo Zoli

matteo.zoli4@unibo.it

1 Pituitary Unit, IRCCS Istituto Delle Scienze Neurologiche di Bologna, Via Altura, 3, 40139 Bologna, Italy

2 Department of Biomedical and Neuromotor Sciences (DIBINEM), University of Bologna, Bologna, Italy

3 Neurosurgery Unit, Fondazione IRCCS Policlinico San Matteo, Pavia, Italy

4 Unit of Anatomic Pathology 'M. Malpighi', Bellaria Hospital, Azienda USL Bologna, Bologna, Italy

5 Neurosurgery Unit, ASST Fatebenefratelli Sacco, Milano, Italy

6 Department of Experimental, Diagnostic and Specialty Medicine (DIMES), University of Bologna, Bologna, Italy

\section{Introduction}

Sellar/parasellar tumors (SPTs) can enlarge during pregnancy as a consequence of multiple mechanisms [1-5]. Pituitary volume physiologically enlarges because of estrogen-stimulated hypertrophy and hyperplasia of lactotroph cells, the last supporting the greater propensity of prolactinomas and pluri-hormonal adenomas to increase in size during pregnancy. In meningiomas, rise of progesterone levels, acting via specific receptors, may further contribute to increase tumor volume and, thus the pressure on nearby neural structures $[1-3,5]$.

In the great majority of the patients with SPTs, pregnancy is uneventful as lesions are typically small and the overall size increase during gestation is not clinically significant [1-3]. Rarely, tumor enlargement can determine mass effect on adjacent anatomic structures, with consequent neurological and visual symptoms [1, 3-25]. Additionally, hormone 
secretion can be impaired by tumor compression of the pituitary gland and deviation of the stalk, or by the presence of a secreting adenoma, with detrimental effects on fetal development and pregnancy outcome [26]. Finally, the increase of adenoma size is associated with a higher risk of pituitary apoplexy and of consequent acute hypopituitarism, typically occurring in the last weeks of pregnancy and at delivery [1-25].

Moreover, the diagnosis of a SPT in pregnancy is particularly challenging. Indeed, physiological modification in size and function, secondary to pituitary adaption to placental hormonal secretion, complicates the interpretation of biochemical and imaging test $[1-3,5]$. Furthermore, CT-scan should be avoided because of ionizing radiations, while the execution of MRI and the administration of gadolinium contrast medium requires precautions, especially in the first trimester [1-3]. Therefore, visual field examination, be repeated at regular intervals, is reported as an useful investigation for SPTs manifesting with visual disturbances in pregnancy, to monitor the further tumor growth [27].

Once diagnosis is established, each case has to be carefully discussed by a multidisciplinary dedicated team made of neuroendocrinologists, anesthesiologists, pituitary neurosurgeons, gynecologists and obstetricians. Indeed, their management has to be patient-tailored with the aim is to restore the mother clinical conditions, while preserving fetus health $[1,5,11,21]$.

Goal of our study is to present our clinical experience and the results of a systematic literature review on the management of SPTs becoming symptomatic during pregnancy. We were, also, aimed to propose a practical algorithm to help clinicians dealing with this condition.

\section{Materials and methods}

Data of patients with SPTs consecutively referred to two Italian referral Centers (IRCCS Istituto delle Scienze Neurologiche di Bologna, Bologna, Italy, and Fondazione IRCCS Policlinico San Matteo, Pavia, Italy) from 2000 to 2019 were retrospectively reviewed to identify cases becoming symptomatic during pregnancy. Clinical, biochemical and radiological data of interest at first evaluation and at follow-up were retrieved from paper and electronic medical records.

At presentation, patients underwent neurological and ophthalmological evaluation-including visual field and visual acuity measurement -, and endocrinological evaluation with biochemical assessment of basal anterior (TSH, free T4, free T3, ACTH, cortisol, prolactin, GH, IGF-I) and posterior pituitary function (serum values of sodium and potassium and plasmatic and urinary osmolarity). An MRI without contrast medium was also performed to confirm the presence and characterize the SPT in all cases. The management of every case was discussed collegially.

Tumor specimens were reviewed and classified according to the WHO classification of 2016 of central nervous system and endocrine organs tumors, respectively [28, 29]. Samples were fixed in $10 \%$ formalin and embedded in paraffin. Tissue was cut into sections of $4-\mu \mathrm{m}$ thickness and stained with hematoxylin and eosin. Immunohistochemical staining was performed by an automatic system (Ventana Benchmark, Ventana Medical Systems, Illkirch, France), using avidin-biotin labeling and diaminobenzidine as detection reagent. Immunohistochemistry was performed using the BenchMark ULTRA Slide Staining System (Roche Diagnostics, Indianapolis, IN, USA). Primary antibodies varied according to the diagnostic suspect [28]. Specifically, anti-chromogranin A (Dako Agilent, Santa Clara, CA, USA; monoclonal Dak-A3; dilution 1:200), pancytokeratin (Novocastra Newcastle, UK; monoclonal AE1 and AE3; dilution 1:50), FSH (Cell Marque, Darmstadt, Germany; monoclonal 83/122A8 antibody; dilution 1:2000), LH (Cell Marque, Darmstadt, Germany; monoclonal 3LH5B6Y antibody; dilution 1:100), TSH (Cell Marque, Darmstadt, Germany; monoclonal 5404 antibody; dilution 1:50), PRL (Biogenex, Fremont, CA, US; monoclonal BGX031A; dilution 1:50), ACTH (Dako Agilent, Santa Clara, CA, US; monoclonal, clone 02A3; dilution 1:1000), GH (Cell Marque, Darmstadt, Germany; monoclonal 54/92A2; dilution 1:50), Steroidogenic Factor 1 (Abcam, Cambridge, UK; monoclonal EPR19744; 1:150), PIT1 (Novus Biologicals, Abingdon Oxon, UK; polyclonal; dilution 1:100), TPIT (Atlas Antibodies, Stockholm, Sweden; monoclonal CL6251; $1: 300)$ were used to diagnose and classify pituitary adenomas [28-30]. Anti-EMA (Novocastra, Newcastle, UK; monoclonal GP1.4; dilution 1:500) and anti- progesterone receptor (Ventana, Oro Valley, AZ, US; 1E2 clone; pre-diluted) were used for the diagnosis of meningiomas; anti-vimentin (Dako Agilent, Santa Clara, CA, US; monoclonal SRL-33; dilution 1:200), anti-S-100 (Dako Agilent, Santa Clara, CA, US; polyclonal; dilution 1:1000), GFAP (Dako Agilent, monoclonal 6F2; dilution 1:1000), TTF-1 (Novocastra, Newcastle, UK; monoclonal SPT24; dilution 1:50; and Dako Agilent, Santa Clara, CA, US; 8G7G3/1; dilution 1:100) and EMA (Novocastra, Newcastle, UK; monoclonal GP1.4; dilution 1:500) for pituicytoma; antib-catenin (Ventana/ Roche, monoclonal clone 14; dilution 1:1) for the identification of craniopharyngiomas and antiBRAFV600E (Ventana, VE1 clone; prediluted) for differential diagnosis between adamantinomatous and papillary subtype [28, 29].

Exeresis was considered radical in the absence of tumor remnants at the MRI; subtotal if the remnant was $<20 \%$, partial if $20-50 \%$, and incomplete if $>50 \%$ of the initial 
mass. Endocrinological, ophthalmological and neurological evaluations, as well as biochemical and functional tests, were repeated 1, 3, 6 and 12 months after surgery, then annually. MRI was repeated 3 months after surgery, then every 6-12 months, depending on the clinical, radiological and histological features, following international guidelines.

\section{Literature review}

\section{Search strategy}

Systematic literature review was performed in accordance with the Preferred Reporting Items for Systematic
Reviews and Meta-analyses (PRISMA) guidelines (Fig. 1). MEDLINE database was queried using keywords and MeSH terms in different combinations using the Boolean operators "AND" or "OR", and database-related filters to maximize the chance to identify articles focusing on surgical management of patients with SPTs developing symptoms during pregnancy. The string (('brain tumor' OR 'brain tumour' OR 'pituitary tumor' OR 'pituitary tumour' OR 'sellar lesion' OR 'pituitary disease') AND pregnancy) was entered. Search was limited to original studies written in English, performed in human subjects and published after 2000 (in the same time frame of our case series). After duplicate removal, articles were screened on the basis of the title and the abstract; for those deemed appropriate, the full text was obtained and

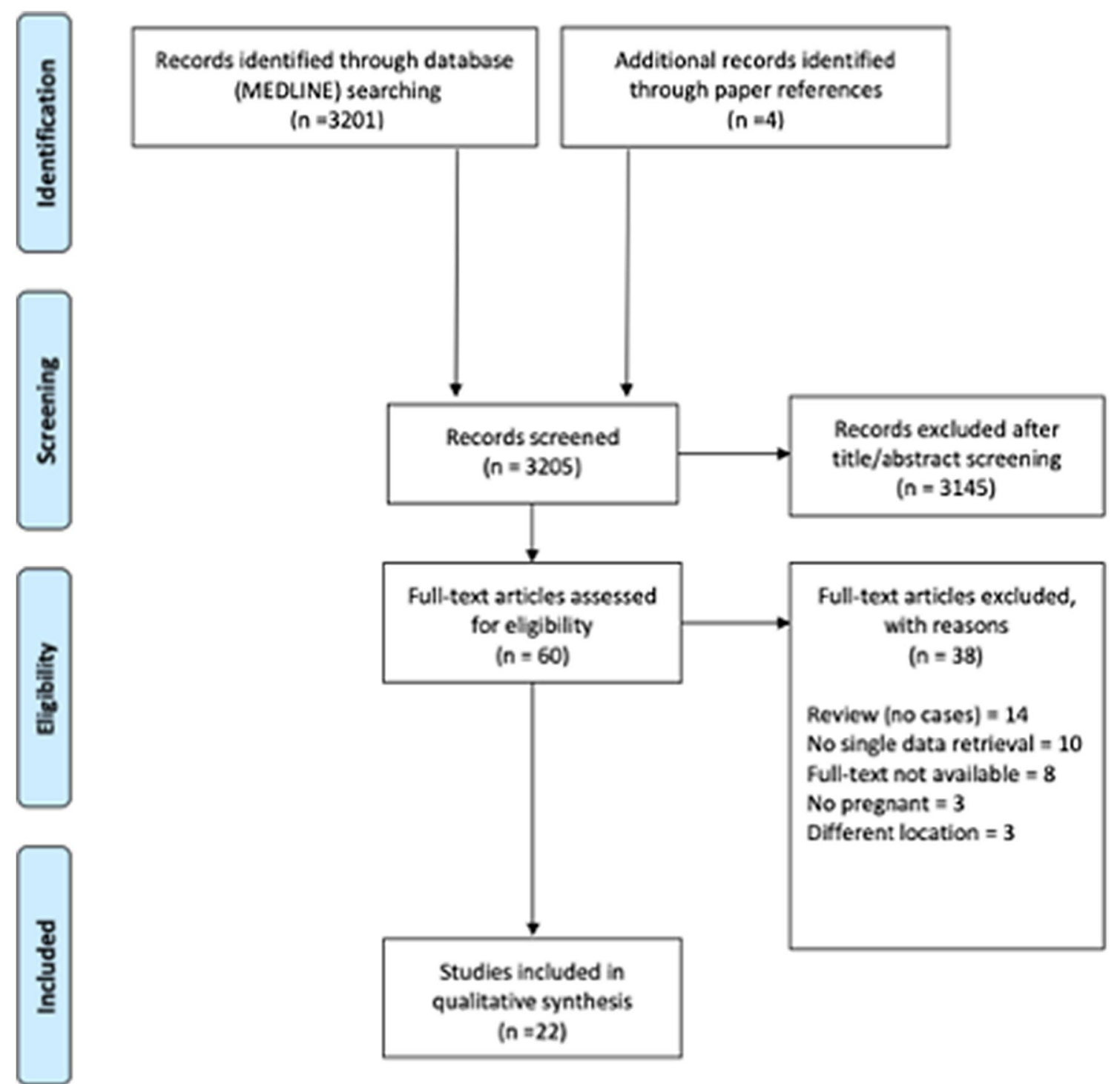

Fig. 1 Flow-chart applied to the retrieval and selection of studies included in literature review 
reviewed, and data of interest were extracted. Reference list of selected articles was examined to identify other potentially relevant studies.

\section{Selection criteria}

Only original studies reporting patients with SPTs developing symptoms during pregnancy with clinical, radiological and histological data of interest were included. Articles were excluded if lesions did not primarily involve the sellar/parasellar region, or the disease manifested after delivery. Studies including different surgical procedures and/or patient populations were included only if sufficient data about the management of SPT in each patient could be obtained.

\section{Data analysis}

Personal and literature data were tabled and analyzed using Microsoft Excel 2019 (Microsoft Corp, Redmond, WA). Collected variables included patient age, gestational week and symptoms at diagnosis; gestational week and type of delivery; pregnancy outcome; treatment type, timing (with respect to pregnancy) and outcome. Data were expressed as mean $\pm \mathrm{SD}$.

\section{Results}

The series included 6 cases: 3 meningiomas, 1 craniopharyngioma, 1 ACTH-secreting adenoma and 1 pituicytoma, managed at the Pituitary Unit of the IRCCS Istituto delle Scienze Neurologiche di Bologna, and at the Neurosurgical Department of the Fondazione IRCCS Policlinico San Matteo, Pavia (Italy), since 2000 to 2019. In the same period, other 14 pregnant patients affected by SPTs (or diagnosed before pregnancy and untreated with medical or wait and see approach or treated but with MRI-detectable remnant at last follow-up performed before pregnancy) were managed at our Centers. Specifically, 11 patients were affected by pituitary adenomas -6 prolactin-, $2 \mathrm{GH}-$ and 1 ACTH-secreting, and 2 nonfunctioning -, 2 by meningiomas and 1 by craniopharyngioma.

At presentation, patient age was $33.6 \pm 6.0$ years and gestation week was $29.8 \pm 4.7$. Presenting symptoms were visual disturbances $(n=5)$, diplopia $(n=1)$, headache $(n=1)$ and features suggestive for chronic hypercortisolism $(n=1)$. Two cases (\#3 and \#5) had been previously reported [31, 32]. Significant patient data at presentation are reported in Table 1.

Mother and fetus vital parameters were strictly monitored up to delivery $(n=5)$. Pregnancy was uncomplicated and the newborns were healthy. A patient with ACTH secreting adenoma (case \#2) required pregnancy interruption at 24 weeks of gestation.

Five patients underwent endoscopic endonasal surgery after delivery because of symptoms persistence. Surgery was uneventful. Tumor exeresis was radical in 4 (80\%) cases, while in one with hemorrhagic craniopharyngioma, the first surgery allowed the decompression of the optic nerve and chiasm, and radical resection was achieved by second surgery, performed two years later (Table 2). A patient with cavernous sinus meningioma had spontaneous regression of diplopia after delivery and underwent proton-beam therapy (Table 2).

Mean follow up was $88.6 \pm 28.8$ months. At last evaluation, patients treated with surgery were free from disease, while the one treated with hadrotherapy had a stable tumor remnant (Table 2).

\section{Case illustration}

\section{Case 1}

A 35-year-old woman at 30 weeks of gestation was referred to neurosurgical attention for the onset of severe headache and progressive visual deficit. Visual field examination

Table 1 Main patient clinical features at symptom onset and tumor histotype

\begin{tabular}{lllllll}
\hline Case \# & Age & $\begin{array}{l}\text { Gestational } \\
\text { week }\end{array}$ & Visual symptoms & $\begin{array}{l}\text { Neurological } \\
\text { symptoms }\end{array}$ & Pituitary function & Tumor histotype \\
\hline 1 & 35 & 34 & BTH & Headache & Intact & Pituicytoma \\
2 & 26 & 22 & None & None & Hypercortisolism & ACTH-secreting adenoma \\
$3[32]$ & 43 & 32 & BTH; VAD & None & Intact & Meningioma \\
4 & 37 & 27 & quadrantopia; VAD & None & Intact & Meningioma \\
$5[31]$ & 32 & 30 & BTH; VAD & None & Partial hypopituitarism & Craniopharyngioma \\
6 & 29 & 34 & None & Diplopia & Partial hypopituitarism & Meningioma \\
\hline
\end{tabular}

$B T H$ bitemporal hemianopia, $V A D$ visual acuity deficit 
Table 2 Pregnancy outcome, post-delivery visual, neurological and endocrinological function, treatment type and results

\begin{tabular}{|c|c|c|c|c|c|c|c|c|}
\hline \multirow[t]{2}{*}{ Case \# } & \multirow[t]{2}{*}{ Pregnancy outcome } & \multirow{2}{*}{$\begin{array}{l}\text { Gestational age at } \\
\text { delivery/abortion }\end{array}$} & \multirow{2}{*}{$\begin{array}{l}\text { Type of } \\
\text { delivery }\end{array}$} & \multicolumn{3}{|c|}{ Post delivery function } & \multicolumn{2}{|l|}{ Post-delivery } \\
\hline & & & & Visual & Neurological & Pituitary & Tumor treatment & Outcome \\
\hline 1 & DHB & 34 & cs & $\mathrm{n}$ & $\mathrm{n}$ & $\mathrm{i}$ & EES & RR \\
\hline 2 & Abortion & 24 & - & $\mathrm{i}$ & $\mathrm{i}$ & $\mathrm{i}$ & EES & $\mathrm{RR}$ \\
\hline 3 [32] & DHB & 34 & cs & $\mathrm{n}$ & $\mathrm{i}$ & $\mathrm{i}$ & EES & $\mathrm{RR}$ \\
\hline 4 & DHB & 34 & cs & $\mathrm{n}$ & $\mathrm{i}$ & $\mathrm{i}$ & EES & RR \\
\hline $5[31]$ & DHB & 33 & cs & $\mathrm{n}$ & $\mathrm{i}$ & panhypopituitarism & EES & SR \\
\hline 6 & DHB & 35 & cs & $\mathrm{i}$ & $\mathrm{n}$ & $\mathrm{i}$ & Proton therapy & Stability \\
\hline
\end{tabular}

cs cesarian section, $D H B$ delivery of a healthy baby, EEA endoscopic endonasal approach, $I$ intact, $n$ normalization, $R R$ radical resection, $S R$ subtotal resection

revealed an incomplete bitemporal hemianopia. Basal pituitary function was preserved. Fetus vital parameters and development were normal for gestational age. MRI demonstrated the presence of an endo- and suprasellar tumor, compressing the optic chiasm. Wait and see approach with close patient and fetus clinical monitoring and repetition of visual field examination was chosen.

Because of patient persistently complained of anxiety and discomfort associated with visual disturbances, despite the stability of the visual field, after careful gynecologicalobstetrician counseling with the evaluations of risks and benefits for the mother and fetus health, elective Caesarian section was performed at 34 weeks of gestation, with no complications. For the potential spontaneous mass reduction, and consequent resolution of compressive effects, after the cessation of pregnancy-associated hormone hyperstimulation, we decided postpone surgery. Since no spontaneous tumor reduction at MRI (Fig. 2a) nor improvement of visual symptoms occurred, the patient underwent elective endoscopic endonasal surgery two weeks after delivery. Tumor resection was radical and uneventful (Fig. 2b). Histopathological examination revealed the presence of bipolar spindled cells arranged in fascicular or storiform pattern, with strong and diffuse staining for vimentin, and nuclear expression of TTF1. GFAP varied from focal to moderate and patcy. EMA staining pattern was patchy and prevalent in cytoplasm. The Ki67 index was low $(<2 \%)$. All these features are typical of pituicytoma.

At last follow-up, performed 101 months after surgery, visual field and pituitary function were restored.

\section{Case 2}

A 26-year-old primigravida was referred at 20 weeks of gestation to endocrinological attention for excessive weight gain, facial rubeosis and diffuse increase of body hair from the $16^{\text {th }}$ week of pregnancy. Biochemical evaluations performed in different days demonstrated increased levels of morning serum cortisol (25.7-28.1; n.v. 4-22.3 $\mu \mathrm{g} / \mathrm{dl})$, plasma ACTH (102.3-95.8 pg/ml; n.v. 5-46), 24-h urine free cortisol (UFC, 876-1088 $\mu \mathrm{g} / 24$ h; n.v. 58-403), and midnight salivary cortisol $(1.7-2.3$; n.v. $<0.2 \mathrm{mg} / \mathrm{dl})$, together with the absence of cortisol suppression at both low- and high dose dexamethasone suppression test.

The clinical and biochemical picture were suggestive for Cushing's disease, despite the important diagnostic limitations associated with pregnancy [6]. Fetal development and vital signs were in the normal range, therefore a wait and see strategy was chosen. Unfortunately, severe hypertension and diabetes mellitus occurred at 22 weeks of gestation. Because of symptoms worsening and the high risk of mother and fetus complications, after obstetrician consultation, patient opted for pregnancy interruption 2 weeks later.

Subsequent biochemical examination confirmed cortisol hypersecretion (morning serum cortisol $26.1 \mathrm{ng} / \mathrm{ml}$; plasma ACTH 84 pg/ml, 24-h UFC $998 \mu \mathrm{g} / 24$ h, midnight salivary cortisol $2.1 \mathrm{mg} / \mathrm{dl}$; serum cortisol after low- and high dose dexamethasone suppression test $>2 \mu \mathrm{g} / \mathrm{dL}$ ). Gadoliniumenhanced MRI showed an endo-suprasellar pituitary adenoma, that was removed by endoscopic endonasal approach with no complications (Fig. 2c). Histological examination confirmed the presence of an ACTH-secreting adenoma. Biochemical, clinical and radiological follow-up demonstrated disease remission (Fig. 2d). Two years later, the patient had a spontaneous uncomplicated pregnancy.

\section{Case 3}

A 43-year-old woman at 32 weeks of gestation of her second pregnancy presented to neurosurgical attention for bitemporal hemianopia and significant bilateral reduction of visual acuity in the previous 2 weeks. At admission, visual acuity was $1 / 10$ in the left eye and $4 / 10$ in the right eye. MRI without contrast medium demonstrated the presence of a suprasellar meningioma arising from the tuberculum sellae (Fig. 2e). Basal pituitary function was normal. Fetus vital parameters and development were normal for gestational age. For progressive worsening of visual disturbances, 
Fig. 2 Coronal views of the gadolinium-enhanced T1-weighted pre- and post-operative MRI showing the present of an intrasellar pituicytoma (case \#1) and ACTH-secreting macroadenoma (case \#2) (a, c), and their complete exeresis (b, d). Sagittal view of the gadolinium-enhanced T1-weighted MRI showing a meningioma arising from the tuberculum sellae (e), removed through endoscopic endonasal approach, with the preservation of the pituitary gland and stalk (f) (case \#3). Sagittal views of the pre-operative T2-weighted (g), and post-operative T1-weighted gadolinium-enhanced MRI (h), showing the complete exeresis of a tuberculum sellae meningioma (case \#4). Sagittal views of the gadolinium-enhanced T1-weighted pre- (i) and postoperative MRI (l), showing a suprasellar craniopharyngioma and its total exeresis after the 2nd endoscopic endonasal surgery, respectively (case \#5). Coronal view of the gadolinium-enhanced T1-weighted MRI showing a meningioma occupying the left cavernous sinus (m), and the results of hadronic radiation treatment $(\mathbf{n})$
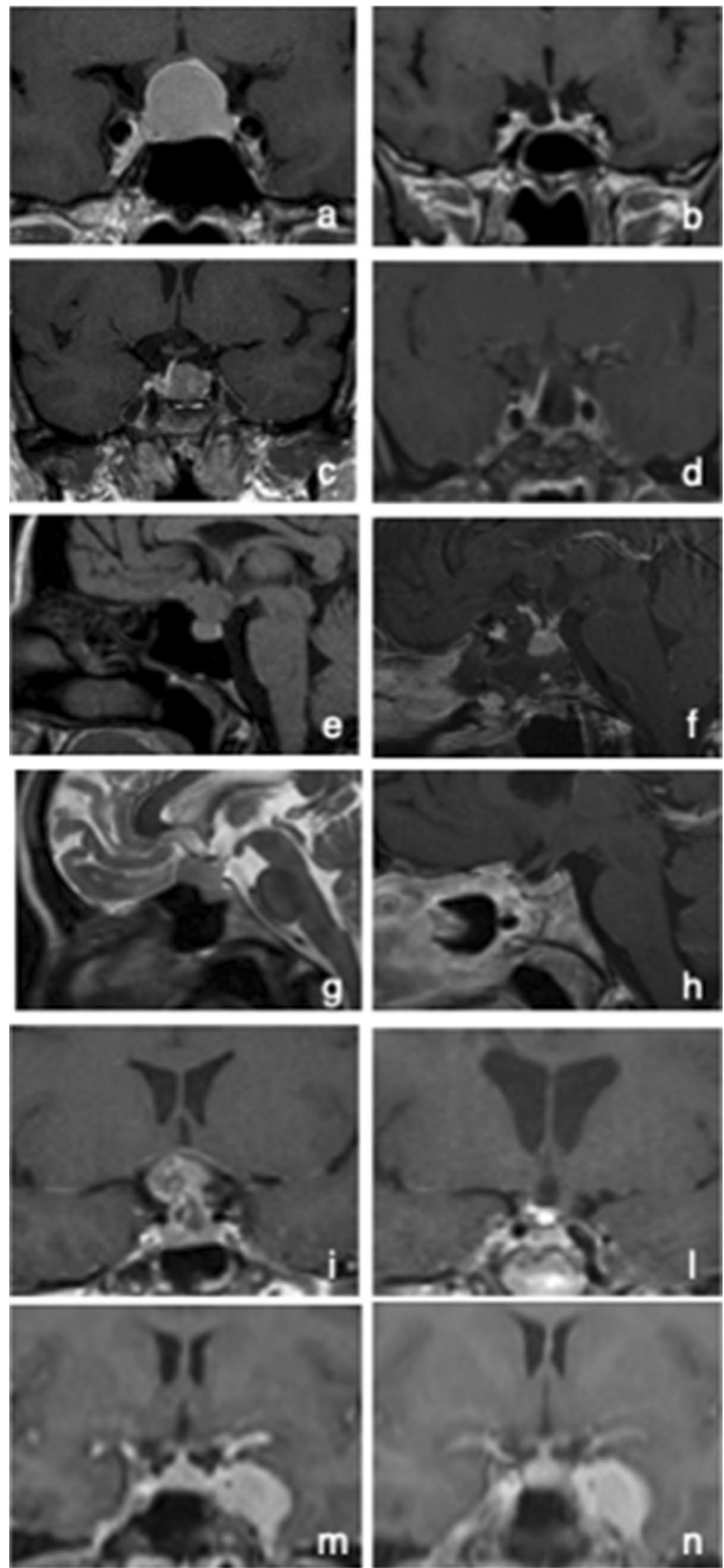
dexamethasone was administered to accelerate the fetal lung maturation, and cesarean delivery was performed at 34 weeks of gestation. The patient underwent endoscopic endonasal surgery 13 days after delivery. Histological examination revealed a meningotheliomatous meningioma (WHO grade 1). Post-surgical evaluations demonstrated normal pituitary function, complete tumor resection and recovery of visual acuity (Fig. 2f).

\section{Case 4}

A 37-year-old woman was referred to neurosurgical attention at 27 weeks of gestation for headache and visual disturbances in the previous month. Visual field examination revealed an infero-temporal quadrantopia associated with residual visual acuity of 2-3/10 in left eye. MRI without contrast medium showed a suprasellar meningioma arising from the tuberculum sellae (Fig. 2g). Basal pituitary function was normal. Fetus conditions and development were normal for gestational age. The clinical and ophthalmologic situation remained stable and after obstetrician evaluation, and corticosteroids administration to induce lung maturation, patient underwent caesarian delivery at 34 weeks of gestation. Tumor removal by endoscopic endonasal was performed 15 days after surgery. Visual disturbances completely regressed. MRI demonstrated the radical resection of the tumor, consisting of a meningotheliomatous meningioma (WHO grade 1) (Fig. 2h).

\section{Case 5}

A 32-year-old woman was referred to neurosurgical attention at 30 weeks of gestation for severe bilateral reduction of visual acuity. Visual field examination documented temporal hemianopia in the right eye and an inferior-temporal field cut on the left. MRI showed an extra-axial lesion in the intra- and suprasellar region, isointense in T1-weighted and iso-hyperintense in long-TR sequences (Fig. 2i). Wait and see approach with close mother and fetus monitoring was chosen. In the meanwhile, corticosteroids were started to induce lung maturation and treat central hypocortisolism, diagnosed at hospital admission.

For the worsening in visual acuity and narrowing of visual field, delivery via caesarean section was performed at 33 weeks of gestation. MRI performed with contrast medium on the same day showed a recent intra-tumoral hemorrhage, that was confirmed at surgical inspection. The patient underwent endoscopic transsphenoidal surgery with subtotal tumor resection and decompression of the optic chiasm, with significant improvement at visual field examination. Histological examination revealed an adamantinomatous craniopharyngioma. For the progressive growth of the tumor remnant in the subsequent 2 years, the patient underwent second endoscopic transsphenoidal surgery with radical tumor exeresis (Fig. 21).

\section{Case 6}

A 29-year-old woman was referred to neurosurgical attention at 34 weeks of gestation for diplopia in all directions of gaze associated with a meningioma of the left cavernous sinus. Basal pituitary function was normal. Fetus development and vital parameters were normal for gestational age. Wait and see approach with close clinical monitoring was chosen. Clinical conditions remained stable. A cesarean section was performed at the 35 th week of gestation, after obstetrician indication after careful evaluations of benefits and risks for mother and foetus. The MRI performed with contrast medium confirmed the presence of a meningioma growing in the left cavernous sinus (Fig. 2m). Diplopia spontaneously disappeared in the following weeks. Three months later the patient underwent hadrontherapy (total dose 55.8 Gy in 31 fractions, administered using IMPT-Intensity Modulated Particle Therapy-technique). At last follow-up, performed 32 months later, tumor dimensions were stable with no neurological symptoms, nor endocrinological deficits (Fig. 2n).

\section{Literature review}

Systematic literature review led to the identification of 50 cases of SPT, clinically presenting in pregnancy [1, 3-25]. At diagnosis, patient age was $31.8 \pm 5.1$ years (range 18-43; data available for 47 patients) and gestational week was $26.0 \pm 7.5$ (range 5-40; data available for 46 cases). Gestational age at symptom presentation was $24.2 \pm 7.3$ weeks (range 5-40; data available for 38 cases). Symptoms mainly occurred in the second trimester (57.9\%), less frequently in the third (36.8\%) and rarely in the first (5.2\%) (Table 3). Reduction of visual acuity was the most common symptom ( $86 \%$ of the cases) followed by headache (18\%), nausea (8\%), retro-orbital pain (8\%) and oculomotor nerve palsy (6\%); proptosis, ophtalmoplegia, facial numbness, sinus congestion, cognitive impairment and loss of consciousness were sporadically reported. Two patients presented with features suggestive for acromegaly (Table 3 ).

Meningiomas (25 cases; $50 \%$ ) were the most common lesions, followed by pituitary adenomas ( 22 cases, $44 \%$ : 11 PRL-, 3 GH-secreting, and 8 non-functioning), 12 (54.5.\%) of which presenting with apoplexy. A case of adenoidocystic carcinoma, a pituitary abscess and a mucocele were reported (Table 3).

Pregnancy was uneventful in the great majority of the cases. Complications jeopardizing the mother and the fetus 
Table 3 Results of literature review: patient features, disease manifestations and pregnancy outcome

\begin{tabular}{|c|c|c|c|c|c|c|c|c|}
\hline Author, year & Age (years) ${ }^{\mathrm{a}}$ & Tumor type & $\begin{array}{l}\text { Gestational age } \\
\text { at evaluation } \\
\text { (weeks) }\end{array}$ & $\begin{array}{l}\text { Gestational age } \\
\text { at symptom } \\
\text { onset (weeks) }\end{array}$ & $\begin{array}{l}\text { Presenting } \\
\text { symptoms }\end{array}$ & $\begin{array}{l}\text { Pregnancy } \\
\text { course/compli- } \\
\text { cations }\end{array}$ & $\begin{array}{l}\text { Gestational } \\
\text { age at delivery } \\
\text { (week) }\end{array}$ & $\begin{array}{l}\text { Mode of } \\
\text { delivery }\end{array}$ \\
\hline \multirow{4}{*}{$\begin{array}{l}\text { Zhong et al. } \\
2019 \text { [25] }\end{array}$} & 36 & TS-M & N/A & 18 & VD & $\mathrm{R}$ & 36 & cs \\
\hline & 29 & NFPA & N/A & 14 & VD & $\mathrm{R}$ & 40 & $\mathrm{vl}$ \\
\hline & 28 & $\begin{array}{r}\text { Pituitary } \\
\text { abscess }\end{array}$ & N/A & 10 & VD; H; nausea & $\mathrm{R}$ & Abortion & - \\
\hline & 36 & TS-M & N/A & 22 & VD & Pre-eclampsia & 38 & cs \\
\hline \multirow{3}{*}{$\begin{array}{l}\text { Jemel et al. } \\
2019 \text { [24] }\end{array}$} & 32 & PRL-PA (PAp) & 37 & 20 & $\mathrm{VD} ; \mathrm{H}$ & $\mathrm{R}$ & 37 & $\mathrm{vl}$ \\
\hline & 35 & PRL-PA (PAp) & 22 & 21 & VD; H & $\mathrm{R}$ & 37 & $\mathrm{vl}$ \\
\hline & 30 & NFPA (PAp) & 24 & 24 & VD; H & $\mathrm{R}$ & 38 & $\mathrm{vl}$ \\
\hline $\begin{array}{l}\text { Bachmeier } \\
\text { et al. } 2019 \\
\text { [23] }\end{array}$ & 30 & PRL-PA & 36 & N/A & VD; H & $\mathrm{R}$ & 37 & cs \\
\hline $\begin{array}{l}\text { Ennaifer et al. } \\
2018 \text { [22] }\end{array}$ & 43 & PRL-PA & 36 & 36 & $\mathrm{H}$; eye ptosis & $\mathrm{R}$ & 40 & $\mathrm{vl}$ \\
\hline \multirow[t]{2}{*}{$\begin{array}{c}\text { Karaca et al. } \\
2018 \text { [3] }\end{array}$} & N/A & GH-PA & 11 & N/A & $\begin{array}{l}\text { Acromegalic } \\
\text { features }\end{array}$ & $\mathrm{R}$ & N/A & $\mathrm{vl}$ \\
\hline & N/A & GH-PA (PAp) & 11 & N/A & $\begin{array}{l}\text { Ophtalmople- } \\
\text { gia }\end{array}$ & $\mathrm{R}$ & 32 & cs \\
\hline \multirow[t]{5}{*}{$\begin{array}{l}\text { Priddy et al. } \\
2018 \text { [21] }\end{array}$} & 25 & Petro-clival M & 5 & 5 & $\begin{array}{l}\text { Arm numb- } \\
\text { ness,; ROP; } \\
\text { weakness }\end{array}$ & $\mathrm{R}$ & Abortion & - \\
\hline & 31 & Sellar M & 29 & 26 & VD; proptosis & $\mathrm{R}$ & 34 & $\mathrm{cs}$ \\
\hline & 29 & $\begin{array}{c}\text { Cavernous } \\
\text { sinus M }\end{array}$ & 18 & N/A & $\begin{array}{l}\text { Diplopia; CN } \\
\text { III palsy; } \\
\text { ROP }\end{array}$ & $\begin{array}{l}\text { acute symptom } \\
\text { worsening at } \\
33 \mathrm{GW}\end{array}$ & 35 & $\mathrm{vl}$ \\
\hline & 32 & $\begin{array}{l}\text { Adenoid cystic } \\
\text { carcinoma }\end{array}$ & $>26$ & N/A & $\begin{array}{l}\text { VD; ROP; } \\
\text { facial numb- } \\
\text { ness; sinus } \\
\text { congestion }\end{array}$ & $\mathrm{R}$ & NA & N/A \\
\hline & 18 & ACP mucocele & $14-26$ & N/A & VD & $\mathrm{R}$ & NA & N/A \\
\hline $\begin{array}{l}\text { Xia et al. } 2018 \\
\text { [20] }\end{array}$ & 25 & PRL-PA & 24 & 24 & VD; H & $\mathrm{R}$ & 38 & cs \\
\hline $\begin{array}{l}\text { Yamaguchi } \\
\text { et al. } 2016 \\
\text { [19] }\end{array}$ & 35 & PRL-PA & 36 & 36 & VD; ROP & $\mathrm{R}$ & 37 & cs \\
\hline \multirow[t]{2}{*}{$\begin{array}{l}\text { Galvão et al. } \\
2017 \text { [18] }\end{array}$} & 30 & PRL-PA (PAp) & 28 & 28 & $\begin{array}{c}\text { consciousness } \\
\text { loss; VD; H }\end{array}$ & $\mathrm{R}$ & N/A & N/A \\
\hline & N/A & PRL-PA (PAp) & 25 & 25 & $\mathrm{VD} ; \mathrm{H}$ & $\mathrm{R}$ & N/A & N/A \\
\hline $\begin{array}{l}\text { Tandon et al. } \\
2014 \text { [17] }\end{array}$ & 27 & PRL-PA (PAp) & 19 & 19 & VD; H; nausea & $\begin{array}{l}\text { acute symptom } \\
\text { worsening at } \\
36 \mathrm{GW}\end{array}$ & 37 & cs \\
\hline \multirow{2}{*}{$\begin{array}{l}\text { Verheecke } \\
\text { et al. } 2014 \\
{[16]}\end{array}$} & 34 & CS-M & 31 & 31 & VD & $\mathrm{R}$ & 35 & cs \\
\hline & 34 & CS-M & 27 & 27 & VD; H; nausea & $\mathrm{R}$ & 33 & $\mathrm{cs}$ \\
\hline \multirow{4}{*}{$\begin{array}{l}\text { Moscovici } \\
\text { et al. } 2014 \\
\text { [1] }\end{array}$} & 39 & TS-M & 17 & 15 & VD & Pre-eclampsia & 35 & cs \\
\hline & 34 & $\begin{array}{l}\text { SpO en plaque } \\
\text { M }\end{array}$ & 21 & 21 & VD & $\begin{array}{l}\text { Grand mal } \\
\text { seizure }\end{array}$ & 41 & $\mathrm{vl}$ \\
\hline & 33 & TS-M & 28 & 27 & VD & $\mathrm{R}$ & 37 & cs \\
\hline & 34 & ACP-M & 29 & 27 & VD & $\begin{array}{c}\text { Metabolic } \\
\text { acidosis }\end{array}$ & 31 & cs \\
\hline
\end{tabular}


Table 3 (continued)

\begin{tabular}{|c|c|c|c|c|c|c|c|c|}
\hline Author, year & Age (years) ${ }^{a}$ & Tumor type & $\begin{array}{l}\text { Gestational age } \\
\text { at evaluation } \\
\text { (weeks) }\end{array}$ & $\begin{array}{l}\text { Gestational age } \\
\text { at symptom } \\
\text { onset (weeks) }\end{array}$ & $\begin{array}{l}\text { Presenting } \\
\text { symptoms }\end{array}$ & $\begin{array}{l}\text { Pregnancy } \\
\text { course/compli- } \\
\text { cations }\end{array}$ & $\begin{array}{l}\text { Gestational } \\
\text { age at delivery } \\
\text { (week) }\end{array}$ & $\begin{array}{l}\text { Mode of } \\
\text { delivery }\end{array}$ \\
\hline & 42 & ACP-M & $\begin{array}{l}24 \text { (diagnosis } \\
\text { after deliv- } \\
\text { ery) }\end{array}$ & 24 & $\begin{array}{l}\text { VD; cognitive } \\
\text { impairment }\end{array}$ & $\mathrm{R}$ & 39 & $\mathrm{vl}$ \\
\hline & 35 & ACP-M & 34 & 28 & VD & $\mathrm{R}$ & 38 & $\mathrm{vl}$ \\
\hline & 34 & ACP-M & 35 & 30 & CN III palsy & $\mathrm{R}$ & 36 & $\mathrm{cs}$ \\
\hline & 35 & TS-M & 32 & 17 & VD & $\mathrm{R}$ & 38 & $\mathrm{vl}$ \\
\hline & 40 & TS-M & 34 & 24 & VD & $\mathrm{R}$ & 36 & $\mathrm{cs}$ \\
\hline & 36 & TS/ACP-M & 32 & 18 & VD & $\mathrm{R}$ & 39 & cs \\
\hline & 28 & ACP-M & $\begin{array}{l}\text { Delivery (diag- } \\
\text { nosis after } \\
\text { delivery) }\end{array}$ & 38 (delivery) & VD & $\mathrm{R}$ & 38 & $\mathrm{vl}$ \\
\hline $\begin{array}{l}\text { Chegour et al. } \\
2014 \text { [15] }\end{array}$ & 19 & PRL-PA (PAp) & 19 & 19 & VD; H & $\mathrm{R}$ & N/A & N/A \\
\hline $\begin{array}{c}\text { Shitara et al. } \\
2012[14]\end{array}$ & 29 & TS-M & 17 & 15 & VD & $\mathrm{R}$ & $>36$ & N/A \\
\hline $\begin{array}{l}\text { Kita et al. } 2012 \\
\text { [13] }\end{array}$ & 26 & NFPA (PAp) & 26 & 26 & VD; H & $\mathrm{R}$ & 40 & $\mathrm{vl}$ \\
\hline \multirow[t]{6}{*}{$\begin{array}{c}\text { Nossek et al. } \\
2011 \text { [12] }\end{array}$} & 29 & PA & 33 & N/A & VD & $\begin{array}{l}\text { Early contrac- } \\
\text { tions }\end{array}$ & 35 & $\mathrm{cs}$ \\
\hline & 36 & TS-M & 29 & N/A & VD; CSF leak & $\mathrm{R}$ & 38 & $\mathrm{cs}$ \\
\hline & 35 & TS-M & 29 & N/A & VD & $\mathrm{R}$ & 39 & cs \\
\hline & 34 & PA & 25 & N/A & VD & $\mathrm{R}$ & 40 & $\mathrm{vl}$ \\
\hline & 38 & TS-M & 34 & N/A & VD & $\mathrm{R}$ & 36 & $\mathrm{cs}$ \\
\hline & 32 & Petro-clival M & 27 & N/A & $\begin{array}{l}\text { VD; V2-V3 } \\
\text { disesthesia }\end{array}$ & $\begin{array}{c}3^{\text {rd }} \text { nerve palsy; } \\
\text { hemiparesis }\end{array}$ & 34 & $\mathrm{cs}$ \\
\hline $\begin{array}{l}\text { Lynch et al. } \\
2011[11]\end{array}$ & 29 & NFPA (PAp) & 40 & 40 & blindness & $\mathrm{R}$ & 40 & cs \\
\hline \multirow[t]{2}{*}{$\begin{array}{l}\text { Iuliano et al. } \\
2011[10]\end{array}$} & 28 & NFPA (PAp) & 29 & 29 & $\begin{array}{l}\text { VD; photopho- } \\
\text { bia; ROP }\end{array}$ & $\mathrm{R}$ & 39 & N/A \\
\hline & 35 & NFPA (PAp) & 31 & 33 & $\begin{array}{l}\text { diplopia (CN } \\
\text { VI palsy); } \\
\text { ROP }\end{array}$ & $\mathrm{R}$ & 39 & N/A \\
\hline $\begin{array}{c}\text { Chacko et al. } \\
2010 \text { [9] }\end{array}$ & 27 & TS-M & 26 & 24 & $\begin{array}{l}\text { VD; H; nausea; } \\
\text { vomiting }\end{array}$ & $\mathrm{R}$ & 30 & $\mathrm{cs}$ \\
\hline $\begin{array}{c}\text { Ebner et al. } \\
2008 \text { [8] }\end{array}$ & 31 & TS-M & 31 & 25 & VD & $\mathrm{R}$ & 34 & cs \\
\hline $\begin{array}{r}\text { Abid et al. } \\
2008 \text { [7] }\end{array}$ & 25 & PRL-PA & 27 & 27 & $\mathrm{VD} ; \mathrm{H}$ & $\mathrm{R}$ & 39 & $\mathrm{vl}$ \\
\hline $\begin{array}{c}\text { Atmaca et al. } \\
2006 \text { [6] }\end{array}$ & 33 & GH-PA & 29 & 26 & $\begin{array}{l}\text { VD; acromeg- } \\
\text { aly features }\end{array}$ & $\begin{array}{l}\text { sudden loss } \\
\text { of vision } \\
\text { and severe } \\
\text { headaches at } \\
33 \mathrm{WG}\end{array}$ & 33 & $\mathrm{cs}$ \\
\hline
\end{tabular}

$A C P$ anterior clinoid process, $C N$ cranial nerve, $c s$ caesarian section, $C S F$ cerebrospinal fluid, $C S-M$ Cavernous Sinus Meningioma, $H$ headache, $M$ meningioma, N/A not available, $N F P A$ non functioning pituitary adenoma, $P A$ pituitary adenoma, $P A p$ pituitary apoplexy, $R$ regular, $R O P$ retro-ortbital pain, $S p O$ spheno-orbital, $T S-M$ Tuberculum Sellae Meningioma, $V D$ visual disturbances, $v l$ vaginal labor

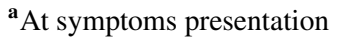


health and life consisted of 2 cases of pre-eclampsia, 1 of grand mal seizures and 1 of metabolic acidosis. Two abortions were also reported. Mean gestational week at delivery was $36.8 \pm 2.6(30-33: \mathrm{n}=5 ; 34-37: \mathrm{n}=18 ; 35-41: \mathrm{n}=19$; data available for 42 patients). Delivery was by caesarian section in $62.5 \%$ of the cases and by vaginal labor in $37.5 \%$ (data available for 40 patients) (Table 3 ). The newborns were healthy; 3 presented with low Apgar score and in 1 with low birth weight.

Tumor exeresis was performed in $46(92 \%)$ cases, of which during pregnancy 27 (58.7\%), and after delivery in 15 (32.6\%), with similar results in terms of symptoms improvement/recovery, pregnancy course and outcome. Nine patients also received radiation therapy and 3 medical therapy. Three prolactinomas were treated with dopamine agonists during pregnancy with rapid symptoms improvement/resolution. Finally, one patient was not treated (Table 4).

\section{Discussion}

SPTs very rarely become symptomatic during pregnancy, but they can threaten both the mother and the fetus health. Both diagnosis and treatment are very challenging and have to be patient-tailored, balancing the potential for cure and for harm. We reported our experience and the results of a systematic literature review on the management of SPTs.

In line with literature, in our series symptoms mainly occurred in the third trimester, likely because of the progressive tumor growth during pregnancy, as well as for possible intratumor bleeding, favored by the hyperdynamic circulation in the last part of gestation, and pituitary cell hyperplasia driven by placenta hormonal secretion, responsible for mass effect on surrounding structures $[1-3,10]$.

In literature, meningiomas resulted the most common lesions, clinically presenting during pregnancy, followed by prolactinomas. This could be due to the greater propensity of these tumors to increase in size in response to the estrogen progestin drive, and, thus, become symptomatic during gestation, or to their higher prevalence of these neoplasms in the population.[1]. In particular, pituitary adenomas represent about $15 \%$ of intracranial tumors (their prevalence has significantly increased in recent decades and is currently estimated of 115 cases/100,000 in the general population), and prolactinomas account for up to $60 \%$ of all pituitary adenomas (up to $75 \%$ in women), typically affecting women (female:male ratio of 20:1 for microprolactinoma) in reproductive age $[3,33]$. If left untreated, the estimated risk of significant tumor enlargement during pregnancy is reported as $26 \%$ for macro- and $1.4 \%$ for micro-prolactinomas [2,34].

Diagnosis of a SPT in pregnancy is typically suggested by the presence of mass-effect symptoms and supported by assessment of hypothalamic-pituitary function and MRI, performed without contrast medium. It has been reported that physiologic functional and imaging alterations associated with pregnancy, together with the need of preventing the mother and the fetus from potentially harmful examinations, strongly influenced the definition of the diagnostic approach and the result interpretation $[1-3,5]$. The clinical evaluation represented, even more than for the general population, the main stay of the patient follow-up, to guide tumor management.

At this purpose, it worth to be mentioned that surgery represent the first choice in the treatment of SPTs-except for prolactinomas, for which dopamine agonists are privileged-to achieve complete exeresis (whenever possible) or debulking (with the resolution of compressive symptoms) as soon as possible [33]. However, the management of SPTs in pregnancy is still debated.

The main elements to be considered in deciding whether or not attempting surgery are the mother conditions (i.e. symptoms type and progression), the fetus gestational age and vital parameters, and the predicted outcome of the procedure, since neurosurgical procedures during pregnancy can compromise blood flow to the fetus and induce premature labor [12, 20, 21].

Pregnancy is characterized by immunological modifications, hypercoagulability, fluid shifts and increased intraabdominal pressure that significantly increase the maternal and fetal anesthesiological and surgical risk in the intra- and peri-operative time [12]. Therefore, although experience is limited, wait and see approach, as well as medical treatment have to be likewise considered because of several reasons [1-3, 5]. First, lymphocytic hypophysitis should be considered in differential diagnosis with SPTs. Indeed, although this is rare condition, it is typically associated to late pregnancy/post-partum. It can occur in the 2nd and 3rd trimester of pregnancy, especially in patients with other autoimmune disorders and presenting with diabetes insipidus and hypopituitarism associated with mass effect symptoms. Moreover, most of clinical, radiological and biochemical features overlap between hypophysitis and other SPTs, but the former has, often, a spontaneous resolution, overall supporting the wait and see approach in patients with mild to moderate symptom severity and stable conditions [35]. Second, ACTH-secreting tumors are quite rare but associated with high rate of complications for the mother (i.e. hypertension or preeclampsia, diabetes, fractures; more rarely, cardiac failure, psychiatric disorders, infection and maternal death) and the fetus (i.e. prematurity, intrauterine growth retardation, and less prevalently stillbirth, spontaneous abortion, intrauterine death, and hypoadrenalism) [34, 36, 37]. Treatment can be aimed at controlling comorbidities, especially in milder cases discovered late in pregnancy. Anticortisolic drugs can be considered while waiting for pituitary surgery, ideally performed in the 2nd-3rd trimester. To date, very few cases of Cushing's 
Table 4 Results of literature review: type of treatment and outcome

\begin{tabular}{|c|c|c|c|c|c|c|}
\hline Author, year & $\begin{array}{l}\text { Gestational age at } \\
\text { treatment (week) }\end{array}$ & Type of treatment & Surgical approach & $\begin{array}{l}\text { Additional treat- } \\
\text { ment }\end{array}$ & $\begin{array}{l}\text { Post-treatment } \\
\text { outcome }\end{array}$ & Pregnancy outcome \\
\hline \multirow[t]{4}{*}{$\begin{array}{l}\text { Zhong et al. } 2019 \\
\text { [25] }\end{array}$} & 32 & Surgery & EEA & $\begin{array}{l}\text { Supraorbital key- } \\
\text { hole }\end{array}$ & Improvement & DHB \\
\hline & 22 & Surgery & N/A & None & Improvement & DHB \\
\hline & 18 & Surgery & N/A & None & Improvement & abortion \\
\hline & 32 & Surgery & N/A & None & Improvement & DHB \\
\hline $\begin{array}{l}\text { Bachmeier et al. } \\
2019 \text { [21] }\end{array}$ & $\mathrm{PP}$ & Surgery & EEA & None & Recovery & DHB \\
\hline \multirow{3}{*}{$\begin{array}{l}\text { Jemel et al. } 2019 \\
\text { [24] }\end{array}$} & PP & Medical therapy & - & None & Improvement & DHB \\
\hline & 22 & Surgery & mTS & None & Improvement & DHB \\
\hline & 24 & Surgery & EEA & None & Improvement & DHB \\
\hline $\begin{array}{l}\text { Ennaifer et al. } 2018 \\
\text { [22] }\end{array}$ & 36 & Medical therapy & - & None & Improvement & DHB \\
\hline \multirow{3}{*}{$\begin{array}{l}\text { Karaca et al. } 2018 \\
{[3]}\end{array}$} & PP (24) & Surgery & N/A & None & Improvement & N/A \\
\hline & 11 & Surgery & N/A & None & Improvement & DHB \\
\hline & 9 & Surgery & craniotomy & RTx & Improvement & abortion \\
\hline \multirow[t]{4}{*}{$\begin{array}{l}\text { Priddy et al. } 2018 \\
\text { [21]] }\end{array}$} & $>26$ & Surgery & EEA & $\begin{array}{l}\text { Surgery (FTOZ); } \\
\text { RTx }\end{array}$ & $\begin{array}{l}\text { Worsening after } 1^{\text {st }} \\
\text { surgery; subse- } \\
\text { quent improve- } \\
\text { ment }\end{array}$ & N/A \\
\hline & $\mathrm{PP}(1)$ & Surgery & EEA & RTx & Recovery & DHB \\
\hline & $\mathrm{PP}(<18)$ & Surgery & N/A & None & $\begin{array}{l}\text { Stability; metastasis } \\
6 \text { years later }\end{array}$ & N/A \\
\hline & $\mathrm{PP}(>18)$ & Surgery & N/A & None & Recovery & DHB \\
\hline Xia et al. 2018 [20] & 24 & Surgery & EEA & None & Improvement & DHB \\
\hline $\begin{array}{l}\text { Yamaguchi et al. } \\
2016 \text { [19] }\end{array}$ & 36 & Surgery & TS & None & Recovery & DHB \\
\hline \multirow{2}{*}{$\begin{array}{l}\text { Galvão et al. } 2017 \\
\text { [18] }\end{array}$} & - & None & - & None & Recovery & DHB \\
\hline & 2nd trimester & Surgery & TS & None & $\begin{array}{l}\text { Hypopituitarism; } \\
\text { symptoms recov- } \\
\text { ery }\end{array}$ & DHB \\
\hline $\begin{array}{l}\text { Tandon et al. } 2014 \\
\text { [17] }\end{array}$ & 36 & Surgery & EEA & None & Recovery & DHB \\
\hline \multirow{2}{*}{$\begin{array}{l}\text { Verheecke et al. } \\
2014 \text { [16] }\end{array}$} & PP & Surgery & N/A & RTx & Recovery & DHB \\
\hline & $\mathrm{PP}$ & Surgery & N/A & RTx & Recovery & DHB \\
\hline \multirow{11}{*}{$\begin{array}{l}\text { Moscovici et al. } \\
2014 \text { [1] }\end{array}$} & 20 & Surgery & N/A & RTx & Recovery & DHB \\
\hline & 28 & Surgery & N/A & RTx & $\begin{array}{l}\text { Improvement } \\
\text { followed by } \\
\text { worsening (tumor } \\
\text { regrowth) }\end{array}$ & DHB \\
\hline & 30 & Surgery & N/A & None & Recovery & DHB \\
\hline & 31 & Surgery & N/A & None & Recovery & DHB \\
\hline & PP (7) & Surgery & N/A & None & Recovery & DHB \\
\hline & PP (12) & Surgery & N/A & None & Recovery & DHB \\
\hline & PP (11) & Surgery & N/A & RTx & Recovery & DHB \\
\hline & PP (3) & Surgery & N/A & None & Recovery & DHB \\
\hline & PP (8) & Surgery & N/A & None & Recovery & DHB \\
\hline & $\mathrm{PP}(56)$ & Surgery & N/A & None & Recovery & DHB \\
\hline & $\mathrm{PP}(6)$ & Surgery & N/A & None & Recovery & DHB \\
\hline $\begin{array}{l}\text { Chegour et al. } 2014 \\
\text { [15] }\end{array}$ & 19 & Medical therapy & - & - & Recovery & N/A \\
\hline Shitara et al. 2012 & 19 & Surgery & $\mathrm{Pt}$ & None & Recovery & DHB \\
\hline
\end{tabular}


Table 4 (continued)

\begin{tabular}{|c|c|c|c|c|c|c|}
\hline Author, year & $\begin{array}{l}\text { Gestational age at } \\
\text { treatment (week) }\end{array}$ & Type of treatment & Surgical approach & $\begin{array}{l}\text { Additional treat- } \\
\text { ment }\end{array}$ & $\begin{array}{l}\text { Post-treatment } \\
\text { outcome }\end{array}$ & Pregnancy outcome \\
\hline Kita et al. 2012 [13] & 27 & Surgery & EEA & None & Recovery & DHB \\
\hline \multirow{6}{*}{$\begin{array}{l}\text { Nossek et al. } 2011 \\
\text { [12] }\end{array}$} & 33 & Surgery & TS & None & Recpvery & Low Apgar score \\
\hline & 31 & Surgery & craniotomy & None & Recovery & DHB \\
\hline & 29 & Surgery & craniotomy & None & Recovery & Low Apgar score \\
\hline & 31 & Surgery & TS & None & Recovery & DHB \\
\hline & PP (2 days) & Surgery & craniotomy & None & Recovery & DHB \\
\hline & PP (10 days) & Surgery & craniotomy & None & Recovery & $\begin{array}{l}\text { Low Apgar score: } \\
\text { low birth weight }\end{array}$ \\
\hline $\begin{array}{l}\text { Lynch et al. } 2011 \\
\text { [11] }\end{array}$ & PP & Surgery & N/A & None & Partial recovery & N/A \\
\hline \multirow{2}{*}{$\begin{array}{l}\text { Iuliano et al. } 2011 \\
\text { [10] }\end{array}$} & 30 & Surgery & TS & None & Recovery & DHB \\
\hline & 33 & Surgery & TS & None & Recovery & DHB \\
\hline $\begin{array}{l}\text { Chacko et al. } 2010 \\
\text { [9] }\end{array}$ & $\mathrm{PP}(40)$ & Surgery & N/A & None & Recovery & N/A \\
\hline $\begin{array}{l}\text { Ebner et al. } 2008 \\
\text { [8] }\end{array}$ & $\mathrm{PP}(1)$ & Surgery & $\mathrm{Pt}$ & None & Recovery & DHB \\
\hline Abid et al. 2008 [7] & 27 & Surgery & TS & $\mathrm{B} ; \mathrm{L}$ & Recovery & DHB \\
\hline $\begin{array}{l}\text { Atmaca et al. } 2006 \\
\text { [6] }\end{array}$ & 33 & Surgery & EEA & RTx; SSA & Hypopituitarism & DHB \\
\hline
\end{tabular}

$B$ bromocriptine, $D H B$ delivery of a healthy baby, EEA endoscopic endonasal approach, $F T$ fronto-temporal, FTOZ fronto-orbito-zygomatic, $L$ Lisuride hydrogen, $m T S$ microscopic trans-sphenoidal, N/A not available, $P P$ postpartum, $P t$ pterional, $R T x$ radiotherapy, SSA somatostatin analogues, $T S$ transcranial

disease have been treated with metyrapone and cabergoline during pregnancy. Other drugs should be avoided for the potential teratogenicity and/or lack of information $[34,36]$. Acromegaly does not seem to significantly increase the risk of maternal diabetes mellitus, miscarriage, preterm delivery, nor fetal low birth weight, macrosomia or congenital abnormalities if left untreated during pregnancy. Therefore, surgery should be considered in case of pituitary apoplexy or visual loss. Somatostatin analogues and pegvisomant appear safe $[3,34,36]$.

Considering all these aspects, together with personal experience and literature review, we propose an algorithm for the management of SPTs becoming symptomatic during pregnancy (Fig. 3). In case of onset of peculiar clinical symptoms or signs highly suggestive for SPT (as for instance visual deficits, severe headache, especially if resistant to pain killer, dizziness, nausea, vomiting, papilledema nystagmus, diplopia, cranial nerve palsies or asthenia), we recommend proceeding with biochemical evaluation, followed by MRI without contrast medium, independently from gestational age. Indeed, even at the first trimester, the potential risks associated with MRI have not been proven to be sufficiently high to justify the serious complications potential associated with the evolution of a symptomatic SPT. The appropriate timing at which performing clinical examination and MRI after symptom onset or patient evaluation cannot be defined a priori, since the severity of symptoms (this the acute or sub-acute presentation) and the evolution of each case are unpredictable. A conservative strategy with careful and close clinical monitoring of mother symptoms (i.e. neurological and ophthalmological evaluation, including visual field test, every 7-10 days or in case of significant subjective changes reported by the patients) and fetal status is suggested in the absence of life-threatening conditions or significant risk of permanent visual impairment and radiological features suspicious for malignant lesions. When clinical conditions are stable or slowly progressive, treatment, especially surgery, should be postponed after delivery. After gestational week 33, delivery can be planned, eventually administering corticosteroids to accelerate fetal lung maturation. Pituitary function, neurological and visual examination, and MRI with contrast medium are recommended in the first time after delivery to re-define surgical indications.

In case of life-threatening maternal or fetal conditions, gestation interruption/induced cesarean delivery (depending on gestational age), followed by prompt surgical intervention has to be considered. Alternatively, if tumor resection could resolve the critical state, as in case of hydrocephalus, 


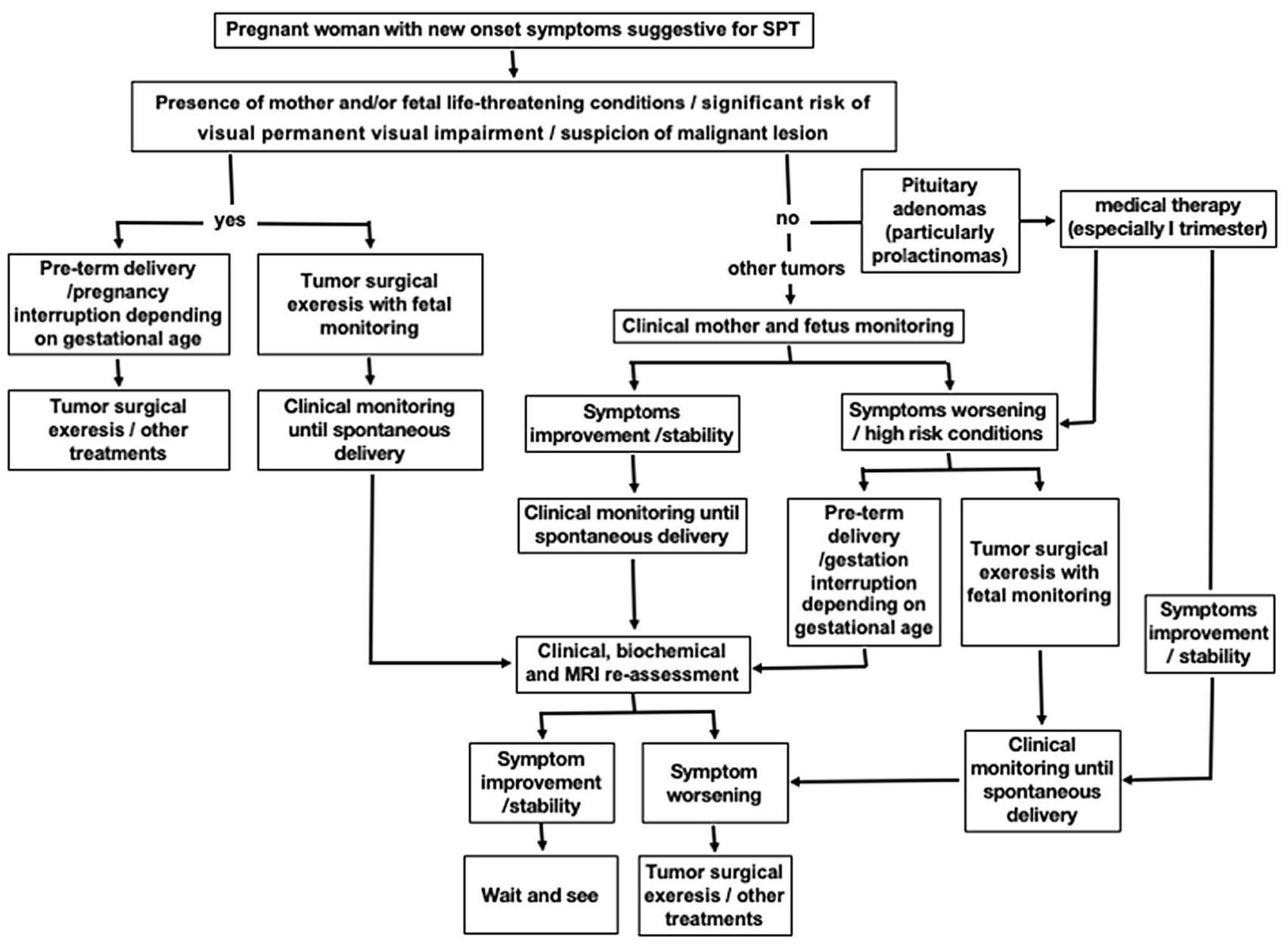

Fig. 3 Suggested algorithm for the management of sellar/parasellar tumors (SPTs) becoming symptomatic during pregnancy

intracranial hypertension or optic nerve compression, surgery during pregnancy with fetal intra-operative monitoring can be performed [25].

Despite intrinsic limitations associated with hormonal evaluations in pregnancy, it is extremely important to identify and characterize pituitary adenomas for the possibility of medical treatment, especially for prolactinomas, for the proven efficacy of dopamine agonists to shrink the volume while controlling hormone secretion, waiting for the appropriate timing/ in substitution of surgery, therefore for these cases surgery should be considered strictly limiting to those patients considered extremely high risk of life-threatening complications, or already treated with dopamine agonists presenting with rapid and significant symptom worsening [26] (Fig. 3).

No specific guidelines exist to define the optimal delivery method. Spontaneous vaginal labor, for the uterine contractions and the extreme Valsalva's maneuver, is associated with an important increase of intracranial pressure, potentially dangerous in patients with a SPT or in the early post-operative time for the risk of CSF leak after a transsphenoidal surgery [21].
Main strength of the study are the systematic literature review and the suggested practical algorithm for the management of SPTs becoming symptomatic during pregnancy, while the retrospective design and the inclusion of different types of tumors, necessary to reach a reasonable number of cases for data analysis, represent not negligible study limitations.

\section{Conclusions}

SPTs becoming symptomatic during pregnancy should be referred to Pituitary Centers, since their management is extremely challenging and requires a dedicated trained team. A practical algorithm to guide physicians dealing with this condition is proposed, overall privileging wait and see approach with careful patient and fetus monitoring, while reserving surgery during pregnancy to clinically unstable patients, with life-threatening/fast worsening situations or suspected malignant lesions. 
Funding Open access funding provided by Alma Mater Studiorum Università di Bologna within the CRUI-CARE Agreement.

Data availability Study results have been presented in part as an oral communication at the 68th Congress of the Italian Society of Neurosurgery, Rome, 16-18th September 2019. Two of the cases reported in this manuscript had also been previously published as case reports (see references 31 and 32).

\section{Compliance with ethical standards}

Conflict of interest The Authors declare that this manuscript is a unique submission and is not being considered for publication with any other source in any medium. The Authors have nothing to declare and nothing to disclose. The Authors declare they have no conflict of interest that could prejudge the content of this manuscript.

Ethical approval The study was approved by an inter-hospital Ethical Committee of Bologna City (protocol \#CE17143, February 2018).

Informed consent All patients gave written informed consent authorizing the use of their clinical data anonymously.

Open Access This article is licensed under a Creative Commons Attribution 4.0 International License, which permits use, sharing, adaptation, distribution and reproduction in any medium or format, as long as you give appropriate credit to the original author(s) and the source, provide a link to the Creative Commons licence, and indicate if changes were made. The images or other third party material in this article are included in the article's Creative Commons licence, unless indicated otherwise in a credit line to the material. If material is not included in the article's Creative Commons licence and your intended use is not permitted by statutory regulation or exceeds the permitted use, you will need to obtain permission directly from the copyright holder. To view a copy of this licence, visit http://creativecommons.org/licenses/by/4.0/.

\section{References}

1. Moscovici S, Fraifeld S, Cohen JE, Dotan S, Elchalal U, Shoshan Y, Spektor S (2014) Parasellar meningiomas in pregnancy: surgical results and visual outcomes. World Neurosurg 82(34):e503-e512. https://doi.org/10.1016/j.wneu.2013.06.019

2. Lambert K, Williamson C (2013) Review of presentation, diagnosis and management of pituitary tumours in pregnancy. Obstet Med 6:13-19

3. Karaca Z, Yarman S, Ozbas I, Kadioglu P, Akturk M, Kilicli F, Dokmetas HS, Colak R, Atmaca H, Canturk Z, Altuntas Y, Ozbey N, Hatipoglu N, Tanriverdi F, Unluhizarci K, Kelestimur F (2018) How does pregnancy affect the patients with pituitary adenomas: a study on 113 pregnancies from Turkey. J Endocrinol Invest 41(1):129-141. https://doi.org/10.1007/s4061 8-017-0709-8

4. Chrisoulidou A, Boudina M, Karavitaki N, Boli E, Wass J (2015) Pituitary disorders in pregnancy. Hormones 14(1):70-80. https:// doi.org/10.14310/horm.2002.1575

5. Bronstein MD, Paraiba DB, Jallad RS (2011) Management of pituitary tumors in pregnancy. Nat Rev Endocrinol 7(5):301-310. https://doi.org/10.1038/nrendo.2011.38

6. Atmaca A, Dagdelen S, Erbas T (2006) Follow-up of pregnancy in acromegalic women: different presentations and outcomes. Expert Clin Endocrinol Diab 114:135-139
7. Abid S, Sadiq I, Anwar S, Hafeez M, Butt F (2008) Pregnancy with macroprolactinoma. J Coll Phys Surg Pak 18(12):787-788

8. Ebner FH, Bornemann A, Wilhelm H, Ernemann U, Honegger J (2008) Tuberculum sellae meningioma symptomatic during pregnancy: pathophysiological considerations. Acta Neurochir (Wien) 150(2):189-193. https://doi.org/10.1007/s00701-007-1417-5

9. Chacko JG, Miller JL, Angtuaco EJ (2010) Spontaneous postpartum resolution of vision loss caused by a progesterone receptor-positive tuberculum sellae meningioma. J Neuroophthalmol 30(2):132-134. https://doi.org/10.1097/WNO.0b013e3181da9d59

10. Iuliano S, Laws ER Jr (2011) Management of pituitary tumors in pregnancy. Semin Neurol 31(4):423-428. https://doi. org/10.1055/s-0031-1293542

11. Lynch JC, Gouvêa F, Emmerich JC, Kokinovrachos G, Pereira C, Welling L, Kislanov S (2011) Management strategy for brain tumour diagnosed during pregnancy. Br J Neurosurg 25(2):225230. https://doi.org/10.3109/02688697.2010.508846

12. Nossek E, Ekstein M, Rimon E, Kupferminc MJ, Ram Z (2011) Neurosurgery and pregnancy. Acta Neurochir (Wien) 153(9):1727-1735. https://doi.org/10.1007/s00701-011-1061-y

13. Kita D, Hayashi Y, Sano H, Takamura T, Hayashi Y, Tachibana O, Hamada J (2012) Postoperative diabetes insipidus associated with pituitary apoplexy during pregnancy. Neuro Endocrinol Lett 33(2):107-112

14. Shitara S, Nitta N, Fukami T, Nozaki K (2012) Tuberculum sellae meningioma causing progressive visual impairment during pregnancy. Case report. Neurol Med Chir (Tokyo) 52(8):607-611. https://doi.org/10.2176/nmc.52.607

15. Chegour H, El Ansari N (2014) Pituitary apoplexy during pregnancy. Pan Afr Med J 17:211. https://doi.org/10.11604/ pamj.2014.17.211.4133

16. Verheecke M, Halaska MJ, Lok CA, Ottevanger PB, Fruscio R, Dahl-Steffensen K, Kolawa W, Mhallem Gziri M, Han SN, Van Calsteren K, Van den Heuvel F, De Vleeschouwer S, Clement PM, Menten J, Amant F, ESGO Task Force 'Cancer in Pregnancy' (2014) Primary brain tumours, meningiomas and brain metastases in pregnancy: report on 27 cases and review of literature. Eur J Cancer 50(8):1462-1471. https://doi.org/10.1016/j. ejca.2014.02.018

17. Tandon A, Alzate J, LaSala P, Fried MP (2014) Endoscopic endonasal transsphenoidal resection for pituitary apoplexy during the third trimester of pregnancy. Surg Res Pract 2014:397131. https ://doi.org/10.1155/2014/397131

18. Galvão A, Gonçalves D, Moreira M, Inocêncio G, Silva C, Braga J (2017) Prolactinoma and pregnancy - a series of cases including pituitary apoplexy. J Obstet Gynaecol 37(3):284-287. https://doi. org/10.1080/01443615.2016.1233946

19. Yamaguchi R, Kohga H, Tosaka M, Sekine A, Mizushima K, Harigaya Y, Yoshimoto Y (2016) A case of optic neuritis concomitant with pituitary tumor during pregnancy. World Neurosurg 93:488.e1-488.e4884. https://doi.org/10.1016/j.wneu.2016.06.103

20. Xia Y, Ma X, Griffiths BB, Luo Y (2018) Neurosurgical anesthesia for a pregnant woman with macroprolactinoma: a case report. Medicine (Baltimore) 97(37):e12360. https://doi.org/10.1097/ MD.0000000000012360

21. Priddy BH, Otto BA, Carrau RL, Prevedello DM (2018) Management of skull base tumors in the obstetric population: a case series. World Neurosurg 113:e373-e382. https://doi.org/10.1016/j. wneu.2018.02.038

22. Ennaifer H, Jemel M, Kandar H, Grira W, Kammoun I, Salem LB (2018) Developed diplopia due to a pituitary macroadenoma during pregnancy. Pan Afr Med J 29:39. https://doi.org/10.11604 /pamj.2018.29.39.12706

23. Bachmeier CAE, Snell C, Morton A (2019) Visual loss in pregnancy. BMJ Case Rep 12(5):e228323. https://doi.org/10.1136/ bcr-2018-228323 
24. Jemel M, Kandara H, Riahi M, Gharbi R, Nagi S, Kamoun I (2019) Gestational pituitary apoplexy: case series and review of the literature. J Gynecol Obstet Hum Reprod 48(10):873-881. https://doi.org/10.1016/j.jogoh.2019.05.005

25. Zhong HP, Tang H, Zhang Y, Luo Y, Yao H, Cheng Y, Gu WT, Wei YX, Wu ZB (2019) Multidisciplinary team efforts improve the surgical outcomes of sellar region lesions during pregnancy. Endocrine 66(3):477-484. https://doi.org/10.1007/s12020-01902054-0

26. Huang W, Molitch ME (2019) Pituitary tumors in pregnancy. Endocrinol Metab Clin North Am 48(3):569-581. https://doi. org/10.1016/j.ecl.2019.05.004

27. Melmed S, Casanueva FF, Hoffman AR, et Kleinberg DL, Montori VM, Schlechte JA, Wass JAH (2011) Diagnosis and treatment of hyperprolactinemia: an Endocrine Society clinical practice guideline. J Clin Endocrinol Metab 96(2):273-288. https://doi. org/10.1210/jc.2010-1692

28. Osamura RY, Grossman A, Korbonits M, Kovacs K, Lopes MBS, Matsuno A, Trouillas J (2017) Pituitary adenoma. In: Lloyd RV, Osamura RY, Kloppel G, Rosai J (eds) World Health Organization classification of tumours of endocrine organs, 4th edn. Lyon, IARC, pp 14-18

29. Louis DN, Perry A, Reifenberger G, von Deimling A, FigarellaBranger D, Cavenee WK, Ohgaki H, Wiestler OD, Kleihues P, Ellison DW (2016) The 2016 World Health Organization classification of tumors of the central nervous system: a summary. Acta Neuropathol 131(6):803-820. https://doi.org/10.1007/s0040 1-016-1545-1

30. Villa C, Vasiljevic A, Jaffrain-Rea ML, Ansorge O, Asioli S, Barresi V, Chinezu L, Gardiman MP, Lania A, Lapshina AM, Poliani L, Reiniger L, Righi A, Saeger W, Soukup J, Theodoropoulou M, Uccella S, Trouillas J, Roncaroli F (2019) A standardised diagnostic approach to pituitary neuroendocrine tumours (PitNETs): a European Pituitary Pathology Group (EPPG) proposal. Virchows
Arch 475(6):687-692. https://doi.org/10.1007/s00428-019-02655 $-0$

31. Zoia C, Cattalani A, Turpini E, Custodi VM, Benazzo M, Pagella F, Carena P, Lovati E, Lucotti P, Gaetani P (2014) Haemorrhagic presentation of a craniopharyngioma in a pregnant woman. Case Rep Neurol Med 2014:435208. https://doi. org/10.1155/2014/435208

32. Zoli M, Faustini-Fustini M, Mazzatenta D, Pasquini E, Frank G (2012) Tuberculum sellae meningioma growing during pregnancy: a difficult decision-making process. J Clin Endocrinol Metab 97(5):1418-1419. https://doi.org/10.1210/jc.2012-115

33. Melmed S (2020) Pituitary-tumor endocrinopathies. N Engl J Med 382(10):937-950. https://doi.org/10.1056/NEJMra1810772

34. Karaca Z, Tanriverdi F, Unluhizarci K, Kelestimur F (2010) Pregnancy and pituitary disorders. Eur J Endocrinol 162(3):453-475. https://doi.org/10.1530/EJE-09-0923

35. Guaraldi F, Giordano R, Grottoli S, Ghizzoni L, Arvat E, Ghigo E (2017) Pituitary autoimmunity. Front Horm Res 48:48-68. https ://doi.org/10.1159/000452905

36. Brue T, Amodru V, Castinetti F (2018) MANAGEMENT OF ENDOCRINE DISEASE: management of Cushing's syndrome during pregnancy: solved and unsolved questions. Eur J Endocrinol 178(6):R259-R266. https://doi.org/10.1530/EJE-17-1058

37. Caimari F, Valassi E, Garbayo P, Steffensen C, Santos A, Corcoy R, Webb SM (2017) Cushing's syndrome and pregnancy outcomes: a systematic review of published cases. Endocrine 55(2):555-563. https://doi.org/10.1007/s12020-016-1117-0

Publisher's Note Springer Nature remains neutral with regard to jurisdictional claims in published maps and institutional affiliations. 